\title{
Reconstruction of Teacher Certification Policies According to Law Number 14 of 2005 Concerning Teachers and Lecturers Based on the Value of Pancasila Justice
}

\author{
Triwahyu Budiutomo $^{1 *}$, Gunarto ${ }^{2}$, Agus Pandoman ${ }^{3}$, Abdul Wahab ${ }^{4}$, Sri Utari ${ }^{5}$ \\ ${ }^{1}$ Doctorate Student of Faculty of Law Sultan Agung Islamic University Semarang, Indonesia \\ ${ }^{2}$ Faculty of Law Sultan Agung Islamic University Semarang, Indonesia \\ ${ }^{3}$ Faculty of Law Cokroaminoto University Yogyakarta, Indonesia \\ ${ }^{4}$ Master Student of Faculty of Law Sultan Agung Islamic University Semarang, Indonesia \\ ${ }^{5}$ Master of Notary Student of Faculty of Law Sultan Agung Islamic University Semarang, Indonesia
}

\begin{abstract}
DOI: $10.36348 /$ sijlcj.2021.v04i03.004
| Received: 21.02.2021 | Accepted: 15.03.2021 | Published: 16.03.2021
\end{abstract}

*Corresponding author: Triwahyu Budiutomo

\section{Abstract}

Teachers are the educators of the nation's next generation, therefore their welfare must be considered by the state and one form of welfare given by the government is teacher's certification. With this certification, teacher salaries can be increased because they are recognized as professionals, but in practice, this teacher certification is still far from perfect because it has not been able to touch all teachers in Indonesia. This encourages the author to conduct research on the subject matter, namely what are the obstacles that arise in the teacher certification process and how the law reconstruction should be based on the value of Pancasila justice where the author uses empirical juridical research methods with primary data obtained from supported fields, Secondary data from literature and statutes analyzed using data triangulation to formulate a conclusion. The results show that the obstacles that arise in implementing teacher certification policies are the weak government support seen by the lack of readiness of the government in implementing policies (availability of human resources and financial resources) which causes the implementation of policies that should be smooth and effective to the contrary, the ambiguity of the Policy, stagnation, and frequent changes in the rules and the length of the policy implementation process as there is a difference in understanding in the implementation of policies as in Article 82 paragraph (2) UUGD where the teacher certification policy should be understood as pre-service training policy, not in-service training. This difference in understanding causes the teacher certification policy to be a policy that has unclear or vague understanding. To overcome this, it is necessary to have a legal reconstruction related to the minimum academic qualifications of teachers to a minimum of S2 (Postgraduate).

Keywords: Reconstruction, Teacher Certification, Pancasila Justice.

Copyright (C) 2021 The Author(s): This is an open-access article distributed under the terms of the Creative Commons Attribution 4.0 International License (CC BY-NC 4.0) which permits unrestricted use, distribution, and reproduction in any medium for non-commercial use provided the original author and source are credited.

\section{INTRODUCTION}

The teacher certification policy as implemented in Indonesia is the government's realization of a teacher's award for their tireless effort in educating the nation's future. The teacher certification policy is a big hope for the Indonesian nation to form teachers who are not only professional and capable of improving the quality of national education but also producing high quality and competitive Indonesian human resources.

However, such goal in its implementation is still not as expected because there has been much violation such as fraud committed by teachers in 400 (four hundred) educational institutions, and the disclosure of the case in Riau, namely the plagiarism of 1700 (one thousand seven hundred) teachers in fulfilling the portfolio [1] has proven that the teacher certification policy has not been implemented justly, honestly and rightfully. Even worse, the working climate, which only disciplines teachers by frightening them with sanctions such as revocation of teacher allowances, barriers to promotion, and so on shows that the teacher certification policy in Indonesia currently is not fair. This, of course, does not educate and does not encourage teachers to progress, therefore, such work climate must be abandoned because this kind of work 
Tri Wahyu et al., Sch Int J Law Crime Justice, Mar, 2021; 4(3): 151-158

pattern is more appropriate for physical workers, for example "heavy laborer" tasked with planting sugarcane during the Culturstelsel era, and this pattern does not provide motivation for the best children of the nation to become teachers. Therefore, the government is obliged to develop an educational work climate that is truly conducive and inspirational so that teachers develop and progress.

The teacher certification policy is an antithesis that develops in such a way in line with changes in science, technology, civilization, and the social environment. Internally related to qualifications, competence, welfare, guarantee of security, and so on. Externally; the moral ethics crisis of the nation's children and the challenges of the global community are marked by high competence, transparency, efficiency, high quality, and professionalism.

Teachers as educational staff substantively play a role not only in teaching or transferring knowledge (cognitive), but also are required to be able to provide guidance and training. The relevance of norms that need to be applied in legal matters should be regulated by regulations that animate the meaning of the teaching profession into a necessity that can be implemented as a measure for a teacher to obtain a certificate of expertise.

The failure of the implementation of the teacher certification policy, according to the author, is due to the fact that the policy in its implementation does not side with the teacher as a professional, the essence of the teacher as a "profession" which refers to expertise.

As emphasized in Article 1 paragraph (1) of Law Number 14 of 2005 concerning Teachers and Lecturers, it is stated that what is meant by: "Teachers are professional educators with the main task of educating, teaching, guiding, directing, training, assessing and evaluating participants. students in early childhood education through formal education, basic education, and secondary education".

Professional is a job or activity that is carried out by a person and becomes a source of living income that requires expertise, skills or abilities that meet certain quality standards or norms and require professional education.

One of the problems with the juridical foundation of the law on teachers and lecturers (UUGD) is indicated by Article 1 paragraph (2) of the Regulation of the Minister of Education and Culture of the Republic of Indonesia Number 87 of 2013 concerning the Pre-service Teacher Professional Education Program that:
"The Pre-service Teacher Professional Education Program, hereinafter referred to as the PPG program, is an educational program held to prepare non-education undergraduate and non-educational S1/DIV graduates who have the talent and interest in becoming teachers in order to fully master teacher competencies in accordance with national education standards so that they can obtain professional educator certificates. in early childhood education, basic education, and secondary education ".

This article is contrary to article 11 paragraph (2) UUGD. The ambiguous and overlapping articles can in fact lead to the fact that the notion of teacher certification will actually eliminate the expertise of the teacher themselves.

This shows that there is no significant difference between teachers who have been certified and teachers who are not yet certified, as the low teacher's professional insight and the fact that teacher attitudes tend to be certificate oriented (certificate oriented) is an indicator that the teacher certification policy has not been based on expertise, but tends to be more emphasizes on administrative aspects only.

The teaching profession is understood to be limited to a job to make money. Teachers are not seen as an (academic) skill but are more likely to be administrative workers, teachers are only understood as part of the field of work, not as their functional value in education [2].

The problems as mentioned above are what urges the author to study the problems further as it is necessary in order to build a better law for teacher wherein this study is concentrated on 2 main problems as follows:

1. What Are The Obstacles That Hinder The Teacher Certification Policy In Indonesia Currently?

2. How Is The Reconstruction Of The Teacher Certification Policy in Indonesia Based On The Value Of Pancasila Justice?

\section{METHOD OF RESEARCH}

This study uses a constructivist legal research paradigm approach. The constructivism paradigm in social science is a critique of the positivist paradigm. According to the constructivism paradigm of social reality that is observed by a person cannot be generalized to everyone, as positivists usually do.

This research uses descriptive-analytical research. Analytical descriptive research is a type of descriptive research that seeks to describe and seek answers fundamentally about cause and effect by 
Tri Wahyu et al., Sch Int J Law Crime Justice, Mar, 2021; 4(3): 151-158

analyzing the factors that cause the occurrence and appearance of a particular phenomenon or event.

The method of approach in research using the method (socio-legal approach). The sociological juridical approach (socio-legal approach) is intended to study and examine the reciprocal relationship that is associated in real terms with other social variables [3].

Sources of data used include primary data and secondary data. Primary data is data obtained from field observations and interviews with sources, While Secondary Data is data consisting of:

1. Primary legal materials, namely binding legal materials in the form of prevailing laws and regulations and have something to do with the issues discussed, among other things, in the form of Legislation related to regional policies in poverty alleviation[4].

2. Secondary legal material, namely legal material whose nature provides an explanation of the primary legal material.

3. Tertiary legal materials are legal materials that provide further information on primary and secondary legal materials.
Research that is associated with the socio-legal approach is research that analyzes problems that are carried out by combining legal materials (which are secondary data) with primary data obtained in the field, supported by prior to secondary legal materials, in the form of writings of experts and existing legal policies [5].

\section{RESEARCH RESULT AND DISCUSSION 1. Obstacles That Hinder The Teacher Certification Policy In Indonesia Currently}

The teacher certification policy has been implemented since 2007, however, the teacher certification program has not been successfully implemented as it still has various problems.

The problem in implementing the teacher certification policy as mentioned above is divided into two categories, namely: quantitative and qualitative failures. In relation to this, the author has conducted research on teacher certification in the special region of Yogyakarta with the following results:

\begin{tabular}{|l|l|c|c|c|}
\hline No & \multicolumn{1}{|c|}{ Elemen } & 2018 & 2019 & 2020 \\
\hline 1 & Kindergarten Teacher (TK) & $6.096,00$ & $6.082,00$ & $6.082,00$ \\
\hline 2 & $\begin{array}{l}\text { School for Disabled Teacher } \\
\text { (SLB) }\end{array}$ & $1.211,00$ & $1.275,00$ & $1.275,00$ \\
\hline 3 & $\begin{array}{l}\text { Junior Highschool Teacher } \\
\text { (SMP) }\end{array}$ & $9.819,00$ & $9.722,00$ & $9.722,00$ \\
\hline 4 & $\begin{array}{l}\text { Senior Highschool Teacher } \\
\text { (SMA) }\end{array}$ & $5.159,00$ & $5.274,00$ & $5.274,00$ \\
\hline 5 & $\begin{array}{l}\text { Technical School Teacher } \\
\text { (SMK) }\end{array}$ & $8.314,00$ & $8.079,00$ & $8.079,00$ \\
\hline Total & $30.599,00$ & $30.432,00$ & $30.432,00$ \\
$(100 \%)$ & $(100 \%)$ & $(100 \%)$ \\
\hline Special region of Yogyakarta from 2018-2020 & $\begin{array}{l}(22,26 \%) \\
(30,04 \%)\end{array}$ & $(30,04 \%)$ \\
\hline Certified Teacher & $\begin{array}{l}(77,74 \%) \\
(6,809\end{array}$ & $9.139,96 \%)$ & $(69,96 \%)$ \\
\hline Total of Teacher Still Uncertified & $21.293,00$ & $21.293,00$ \\
\hline
\end{tabular}


Tri Wahyu et al., Sch Int J Law Crime Justice, Mar, 2021; 4(3): 151-158

Until 2020, out of 30,432 teachers in DIY, only 21,293 teachers were certified $(69.96 \%), 9,139$ were not certified $(30.04 \%)$, a large number.

The data shows that in 2018 - 2019, there was a significant increase in certified teachers, while in 2019 - 2020 the increase was relatively stagnant. According to information from school supervisors, in 2019 - 2020, young teachers are generally completing their S1 advanced study program, while older ones generally have lost their enthusiasm, because they feel that their age will hinder their hopes to take part in the certification program as they had to compete with the younger, and more capable teacher.

As stated by one of the key informants, Eko Joko Santosa [6], As a teacher who also happens to be a teacher operator in DIY, that his opportunity to participate in the teacher certification program is closed.

If the implementation of the teacher certification policy is linked to article 82 paragraph (2), then this means that teachers who have not been able to meet the certification requirements are given ten years to fulfill these requirements. However, the reality is that the quantitative implementation of the teacher certification policy results in a sufficient category, so the level of compliance is mathematically only $69.96 \%$.

The failure to implement the Teacher Certification Policy in DIY is qualitatively measured based on five criteria, namely:

a. Policy Inaccuracy. Viewed from the aspect of inaccurate policies in solving problems, The teacher certification policy has indeed been able to solve the problem as it is indeed able to increase the Teacher's welfare. However, the problem of improving the process and learning outcomes has not been fully achieved because the certification allowance, which should have been allocated to improve the facilities and infrastructure for teaching and learning activities, is mostly used by the teachers for their personal and family needs. The teaching profession is a respectable profession in society because of its function as an educator and because of that, giving teacher certificates to the teacher does not come simply and easily, but through portfolio tests (20062010) and PLPG tests (2011-present), the teaching profession is increasingly recognized, coupled with the provision of professional teacher allowances that can increase the welfare of teachers which makes teachers to be seen higher in their community because of higher salary means a higher standard of living, however, the impact of increasing welfare turned out to have an impact as that was not in accordance with expectations, namely a change in the lifestyle of teachers, from productive to consumptive. b. Inaccurate Implementation of Teacher Certification Policies. Based on Book 2 of the Technical Guidelines for the Implementation of Teacher Certification Policies in 2012, which states that agencies that carry out teacher certification in each region must understand the procedures and mechanisms for implementing teacher certification policies. Referring to the results of research and interviews with informants, who generally are teachers and policy implementers (school principals, school supervisors, and District / City Education Offices in DIY) on the procedures and mechanisms for teacher certification policies shows that the policy implementer has carried out its duties properly according to its main duties and functions, namely the LPTK Rayon as an institution that tests and issues educator certificates for teachers, LPMP as an institution that approves the list of certified teacher candidates and controls the course of teacher certification at the regional level, while the District / City Education Office provides outreach, determines certification participants according to Book 1 of the Guidelines for Determining Certification Participants, and collects data and checks teacher biodata and so on. From the results of the informants' explanations, the institutions that handle teacher certification policies are correct and have carried out the tasks stipulated in the technical guidelines and implementation of teacher certification policies. Even so, the informant conveyed that older teachers generally find it difficult to implement this policy, and indeed if it is examined in-depth, the teacher certification policy should be a pre-service training policy, only applied to prospective teachers, not teachers in office.

c. Inaccuracy of Targets, Based on the results of interviews with key informants, the Teacher Certification in DIY has not met the requirements for the accuracy of the target as it is not according to the targets specified in government regulations. The teacher certification policy targets were not ready when the certification policy was implemented because at that time there were still so many qualified teachers under the S1 / DIV, so teachers had to take S1 / DIV education to get teacher certification. This unpreparedness that occurs is generally related to administration, such as unpreparedness in collecting documents such as certificates, certificates of assistance, Decision Letter from the first appointment to their recent which is sometimes too difficult to find back, and sometimes the required document is lost. The difficulty of collecting these documents is added to the very short time given, which is usually one week to prepare all the required documents. This administrative unpreparedness has resulted in many teachers not able to be certified, this is mainly experienced by non-government employees (PNS) 
Tri Wahyu et al., Sch Int J Law Crime Justice, Mar, 2021; 4(3): 151-158

teachers, so that until this article was made, there are still quite a number of non-PNS teachers who have not been certified educators (until 2020 a total of 9,139 teachers or $3004 \%$ of teachers in DIY are not yet certified)

d. Environmental Inaccuracy. environmental imprecision consists of two things, namely the internal and external environment. The internal environment is the interaction between policy formulating and policy implementing agencies is quite good. However, the shortage of implementing staff and the lack of understanding of teachers on policy essences resulted in problematic teacher certification policies. This shows that public perceptions or opinions regarding teacher certification result in social jealousy, especially for civil servants, other than teachers, who feel that they have something in common, namely as civil servants but teachers get very large allowances while other civil servants do not. In addition, the public also focuses on changes in teacher welfare, which causes the lifestyle of teachers to change, many teachers tend to use the entire certification money for their welfare, such as buying vehicles, renovating houses, performing the hajj pilgrimage, and other religions without being balanced with performance improvements.

e. Inaccuracy of the First Policy Process, namely Policy Acceptance. At this stage, every Education Office in DIY receives an order from the DIY Education Regional Office to carry out the tasks set out in the implementation guidelines, namely the Policy Adoption of the Education Office, where in this stage is starting to prepare everything that is needed during the teacher certification process, starting from determining the staff in charge, preparing the budget ceiling and so on. The Policy Readiness of each Education/ City Office in DIY begins to work on the assignments that are given coherently and regularly every year starting from data collection, checking files, determining teacher lists based on quotas, carrying out competency examinations, and so on. With the accuracy of the policy implementation process, it will soon be seen or recorded, the difficulties of teachers in implementing the teacher certification policy. Safeguarding educational institutions from internal and external desires that could potentially deviate from the prevailing regulations.

\section{Reconstruction of the Teacher Certification Policy in Indonesia Based on the Value of Pancasila Justice}

Various factors covering global trends as well as the economic, social, political, cultural, and geographic dimensions of a country are the basis and background for rolling out and implementing reforms in the field of education. Singapore, for example, is a country that is still quite young with a geographic condition that is not so wide and its natural resources are minimal, but this country is investing its future with full attention to human resources through an education system that is aimed at preparing its young generation to face the challenges of globalization as well as playing an active role in the global economic agenda. A number of Singapore education reform programs such as Thinking School, Learning Nation; Teach Less, Learn More, and the School Excellent Model have proven to be effective in creating quality human resources that can play an active role in the global world scene [7].

Meanwhile, Indonesia as a large country with a diversity of cultures, ethnicities, languages, and religions, accompanied by numerous policies rolled out in the framework of educational reform such as Education decentralization program within the framework of school-based management that is the Education Unit Level Curriculum (KTSP), the 2013 Curriculum, the teacher certification program and so on, and yet, these various programs appear to have not been able to effectively improve the quality of education in Indonesia.

The large wealth of Indonesian resources, both natural resources and human resources, is actually a more challenge for the realization of education reform so that it takes a much longer time and stronger commitment from all elements of the nation to actively work together to realize the ideal of educational reform.

In comparison, in Western Australia, the development of teacher professionalism is organized by the Institute for Professional Learning. The institute accepts applications and organizes teacher education and training according to its chosen career path. There are three career paths provided, namely for senior teachers, level 3 teachers, and school administrators [8].

The senior teacher career path prepares teachers to be teachers only, without the need for other special skills. The grade 3 teacher route prepares class teachers and certain special skills (for example leadership). Meanwhile, the school administrator teacher route prepares teachers to become school principals or head/ deputy heads of local education offices (become a principal, deputy, or head of a learning area).

The implementation of education and training is carried out using training modules, both online, print, and portfolios for grade 3 teacher pathways, then ends with assessment and certification for those who pass.

Public teachers are given training fees of $\$$ 1,600 per year. There is additional income after 
Tri Wahyu et al., Sch Int J Law Crime Justice, Mar, 2021; 4(3): 151-158

obtaining a certificate in accordance with their respective channels. For example, senior teachers earn an additional \$ 91,647 each month.

This system, by comparing to the Indonesian system is almost identical, because there are similarities to the teacher career development system in Indonesia. For example, The Institute for Professional Learning looks similar to PPG in Indonesia. The only difference lies in the executor. other similarities also exist like in Implementing education and training at the Institute for Professional Learning in the education department, while PPG is carried out by appointed LPTKs. The teacher certification system also goes through the portfolio route, similar to the career path for grade 3 teachers in Western Australia, and the training system using modules that has similarities with the implementation of PLPG in Indonesia.

Even though there are similarities, it seems that there are positive things to be developed in Indonesia going forward. For example, the implementation of teacher professional development training and education must be designed from the beginning of the teacher's career, not impromptu. Likewise, the career path for teachers who will become educational institution officials (school principals, supervisors, and heads of education offices) has been determined since the beginning, so that it is independent of certain political interests. Meanwhile, with regard to additional income for teachers who have been certified, it appears to be quantitatively greater in Indonesia.

The government policy on teacher qualifications, competence, and certification whose implementation is in the process is an effort to improve the quality, ability, and welfare of teachers which are expected to have an impact on improving the quality of education in Indonesia.

The teacher certification policy is a policy established by the government to directly intervene in efforts to improve the quality of national education through improving teacher professionalism. The teacher certification policy is a performance appraisal system because teachers will be assessed for their eligibility before they are declared professional teachers.

The teacher certification policy is a breakthrough in the world of education to improve the quality and professionalism of a teacher, so that in the future all teachers must have a certificate as a teaching license or permit.

Licensing for professional educators, which requires difficult requirements, is an effort to form a professional teacher in Indonesia which will soon become a reality and it is hoped that the one who becomes a teacher is dedicated to it and not using it only as a stepping stone to getting a job.

The teacher certification policy is very beneficial for the development of education in schools. The benefits of the certification test are as follows [9]: (1) to protect the teaching profession from incompetent educational service practices that can damage the image of the teaching profession itself; (2) to protect the public from unqualified and professional educational practices that will hinder efforts to improve the quality of education and prepare human resources in this country; (3) To become a vehicle for quality assurance for Educational Personnel Education Institutions (LPTK) which are tasked with preparing prospective teachers and also functioning as quality control for users of educational services; (4) to safeguard educational providers from internal and external desires that could potentially deviate from the prevailing regulations.

The phenomenon associated with teacher certification is that teachers in their position as a instructor (Tenaga Pengajar), that often referred to as the agents of learning, with the education certificate allowance, becomes a certificate-oriented figure, this situation is one of the weaknesses that can reduce the credibility of the teaching profession.

Of the six aspects of implementation weaknesses as described in sub chapter 1, the aspects that have the most weaknesses are aspects of performance review and reward and punishment, where these two aspects are completely absent in the teacher certification process and the factors that influence it are communication, resources, implementor disposition, and the bureaucratic structure of the implementing organization [10].

Apart from having the disadvantages described above, this program also has advantages, including: (1) increasing the skills and abilities of teachers; (2) has the title of Professional Teacher (Gr); (3) obtaining an Educator Certificate; (4) performance criteria that are already related to actual performance, even though they have not been used properly; (5) the method used in the assessment of the practical exam is correct, even though the performance criteria are not clear; (6) get additional allowance.

Based on the foregoing, the authors then formulated that the reconstruction of the teacher certification policy based on the value of Pancasila justice and that is reconstruction related to the minimum academic qualifications of teachers. The difference in the academic qualifications of teachers compared to lecturers has resulted in the emergence of teacher and lecturer to be clustered, therefore it must be equalized. 
Tri Wahyu et al., Sch Int J Law Crime Justice, Mar, 2021; 4(3): 151-158

By equalizing the academic qualifications of teachers equivalent to $\mathrm{S} 2$ through master education institutions (S2), the government's effort to create a professional profession of teacher that is prosperous and balanced both in their right and obligation can be realized as currently, the minimum requirements for academic qualifications in Indonesia are relatively the lowest. For example, Singapore, Australia, and Finland require a minimum academic qualification of a master teacher (S2), while Malaysia starting from 2020 is planning for a minimum academic qualification of teachers to S2 as well.

This is in accordance with the Characteristic of academic justice competencies that is (1) abstract thinking; (2) commitment; (3) academic moral integrity; and (4) academic culture. Is a character that should be owned by the teacher. The reconstruction proposed in this study, in addition to pedagogical competence, personality competence, social competence, professional competence is added to academic justice competence as one of the teacher competencies.

The level of welfare for teachers with private status is still relatively low and is not equal between teachers with public status and those with private status. Meanwhile, the workload and responsibility of teachers as professional educators have resulted in unfair teacher certification policies. The reconstruction proposed in this study is that the central and local governments equalize the income of public and private teachers who already have an educator certificate that is adjusted to the regional minimum wage standards.

Furthermore, although teacher certification is indeed necessary for the welfare of teachers, this also has a negative impact on teacher performance and competence because this makes teachers' actions certificate-oriented, and other activities that aren't relevant to be set aside although those activities may promote the student's growth. Many education observers doubt the effectiveness of the implementation of teacher certification policies as an effort to improve teacher performance. Some even hypothesized that certification would not have any impact on improving teacher performance, let alone related to improving the quality of national education.

Related to the findings in the field that there are indications of teacher weakness in addressing the curriculum. Teachers are not part of the curriculum system, but the success of implementing the curriculum will depend on the abilities, willingness, and professional attitudes of the teachers.

Associated with the professional requirements of a teacher in accordance with National Education Standards. Teachers must be able to plan, develop, implement, and assess the learning process in a relevant and effective manner, so a professional teacher will easily pass the certification without having to manipulate the file. Because previously the teacher has been active in developing himself for their students. It is hoped that this method can bring positive results for the problems raised. So that the problem can be controlled.

The way that can be done as a first step to stem the negative effects resulting from the implementation of the certification policy is by disseminating and increasing the Supervision of Certification.

The certification supervisors, in this case, the assessor team, also need to improve their carefulness and accuracy in certifying the participants, so as not to allow participants to manipulate the documents for their certification requirements. As well as increasing awareness of indications of possible fraud to then advanced to the next step and that is to improve the upgrading for Teachers program in the form of improvements to the quality of teachers in various competencies where this upgrading can be in the form of training activities, upgrading, workshops, and many more.

\section{CONCLUSION}

1. Constraints that rose in the implementation of teacher certification policies in Indonesia are the weak government support, lack of readiness of the government in implementing policies (availability of human and financial resources) which causes the implementation of policies that should be smooth and effective to the contrary, Policy ambiguity, stagnation, and frequent-but not substantial changes in the rules and the length of the policy implementation process, there are differences in understanding in the implementation of policies as in Article 82 paragraph (2) UUGD where teacher certification policies should be understood as preservice training policies, not in-service training. This difference in understanding causes the teacher certification policy to be a policy that has unclear or vague understanding.

2. The reconstruction of the teacher certification policy based on the value of Pancasila justice is related to the minimum academic qualification of the teacher. The difference in the academic qualifications of teachers compared to lecturers has resulted in the emergence of teacher and lecturer to be clustered, therefore it must be equalized, by increasing the academic qualifications of teachers to the equivalent of S2 through master education institutions. This reconstruction proposal is strengthened by the realization of the increasing teacher requirements in several countries which are also at least Strata two (S2), and obtained through master education institutions $\mathrm{S} 2$. 
Tri Wahyu et al., Sch Int J Law Crime Justice, Mar, 2021; 4(3): 151-158

\section{REFERENCES}

1. Adiyanta, F. S. (2019). Hukum dan Studi Penelitian Empiris: Penggunaan Metode Survey sebagai Instrumen Penelitian Hukum Empiris. Administrative Law and Governance Journal, 2(4), 697-709.

2. Aiken, H., Varghese, C., Pedonti, S., BratschHines, M., \& Vernon-Feagans, L. (2020). Targeted Reading Intervention Teacher Certification: An Approach to Building and Sustaining Teacher Expertise in Rural Schools. Literacy Research and Instruction, 59(4), 346-369.

3. Ardana, I. P. (2020). Kontribusi sertifikasi guru, motivasi kerja, dan supervisi akademik kepala sekolah, terhadap kinerja guru smp negeri di kecamatan marga (Doctoral dissertation, UNIVERSITAS PENDIDIKAN GANESHA).

4. HS, D. R. (2017). Plagiarisme dan Korupsi Ilmu pengetahuan. Kordinat, XVI (2), 22.

5. Knoppen, D., Dolan, S. L., Diez-Pinol, M., \& Bell, R. (2006). A triangulation analysis of value congruency in corporate Spain: American dream or

Spanish reality?. The International Journal of

Human Resource Management, 17(3), 539-558.

6. Nurhattati, M., Buchdadi, A. D., \& Yusuf, C. F. (2020). Teacher Certification in Indonesia: An Education Policy Analysis. Universal Journal of Educational Research, 8(5), 1719-1730.

7. Santosa, E. J. (2020). Teacher Certification in Yogyakarta in his Position as a Teacher in Yogyakarta's Industrial Technical School/Interviewer: T. Wahyu.

8. Sapto, Budoyo, J. H., Gunarto. (2017). Desperate needs of teacher's law protection as a professional educator in Indonesia. International Journal of Multidisciplinary Research and Development, 4(7), 191-195. Retrieved from http://www.allsubjectjournal.com/archives/2017/vo 14/issue7/4-6-210

9. Siegel, M., Bowey, P., Du, Y., Cisterna, D., Muslu, N., Murakami, C., Murakami, N. (2020). Experiences of Teacher Certification Testing: Bias, Resistance, and Practical Solutions.

10. Soekanto, S. (1984). Pengantar Penelitian Hukum. Jakarta: UI Press. 